\title{
ECONOMICAL, ENVIRONMENTAL AND SOCIAL SIGNIFICANCE OF LOCAL FOOD SYSTEMS
}

\author{
Ola BAREJA-WAWRYSZUK ${ }^{*}$, Jarosław GOLEBIEWSKI ${ }^{1}$
}

\author{
Address: \\ ${ }^{1}$ Warsaw University of Life Sciences; ul. Nowoursynowska 166; 02-781 Warszawa, Poland \\ *Corresponding author, e-mail: ola bareja@sggw.pl
}

\begin{abstract}
It is observed that quality of mass produced and highly processed food forces consumers to change their consumption habits and become more interested in locally available food products. Consumers are becoming aware of negative consequences of global food systems. As an alternative, Local Food Systems are gaining on popularity because short food supply chains offer fresh, healthy and not modified products. The popularity of Local Food Systems is reflected in the need for analysing impact and significance of those systems. Thus, this paper presents main benefits of acting locally. Local Food Systems has been reviewed in case of positive economic, environmental and social influence on the region. What is more, the paper presents consumers' attitude to Local Food Systems. As a conclusion authors justify significance of development and investment in Local Food Systems as an alternative to agriculture networks.
\end{abstract}

Keywords: Local Food Systems, short food supply chains, sustainability, alternative agriculture networks JEL: R11, Q18

\section{INTRODUCTION}

Modern food sector is dominated by highly efficient production techniques offering mass products on the global market. Intensive production, as well as transportation possibilities, guarantees great availability of food products from all over the world. Undoubtedly, global food systems favour diversification of food sector and give access to products from remote regions. However, recent observation shows that consumers have started to reveal interests in alternative food networks supporting local production. Józef Zegar (2012) argues that society is paying significant costs for industrial, devastating food systems. In his opinion environmental and social costs of globalized agriculture are substantial and cover loss of fertile soil, air and water pollution, loss of biodiversity, dependence on non-renewable resources, growing social inequality, and decline of rural communities or food quality deterioration. Zegar (2012) also claims that the features of industrialized agriculture model that used to testify its advantage now are becoming disadvantages. Due to rise of external costs of global food systems and lack of added value, consumers neglect industrialized agriculture models. Changes in consumption habits focus attention on Local Food Systems (LFS). Thus, the aim of this paper is to review available literature in case of estimating whether Local Food Systems are regarded to have positive effects on economy, society and environment.
What is more, collected data aim to answer whether Local Food Systems can become an alternative for industrialized food model.

The paper consists of three main parts. First of all characteristics of Local Food Systems has been presented. Then authors describe consumers' attitude to Local Food Systems. Next, economic, environmental and social significance of Local Food Systems is analysed. As a conclusion authors summarise significance of Local Food Systems and allude to the paper aim.

Date presented in this paper come from study of literature as well as contains information presented by Central Statistical Office in Poland and European Commission reports.

\section{MATERIAL AND METHODS}

\section{Methods of analysis}

Paper consists of literature study. Due to achieve the paper goal, 23 pieces of literature from Poland and other European countries were analysed and combined presenting significance of Local Food Systems. Moreover, paper presents own analysis of secondary data collected by Eurobarometer (2011) and Central Statistical Office of Poland (2011).

\section{Local Food Systems characteristics}

There are a few definitions of Local Food Systems in the literature. First of all, Local Food Systems are connected with production, processing, sharing and consuming food products in close geographical distance (European 
Commission, 2013). What is more, LFS are the smallest unit of food production where consumers and producers are well known to each other and there is a direct relation between them (Przeglad Obszarow Wiejskich, 2012). Moreover, the element which is "direct relation" imposes the need for minimal amount of intermediaries in supply chain allowing consumer and producer to create social connections (Ilbery B., Maye D., 2006). In the opinion of Renting et al. (2003) shortening of relations between food producer and locality can potentially enhance a reembedding of farming, towards more environmentally sustainable models of production.

Local Food Systems play fundamental role in the world food supply. It is estimated that world's local agribusiness takes $80 \%$ share in general food system (Committee of Regions, 2011). In accordance to the research from IMPACT in UE-1, the proportion of farmers connected with short food supply chains takes over 20\%. Nevertheless, among European countries percentage of farmers offering products locally is variable (Renting et al. 2003). EU is characterized by heterogeneous agriculture systems. Each country represents own agriculture model which decide about country uniqueness (Committee of Regions, 2011). Thus, Local Food System is a great opportunity to offer outstanding products, unique for particular country. Despite the concentration and specific unification of the European Union, the European Commission strongly supports development of short food supply chains and encourages promoting local products by each member country. The Common Agricultural Policy for 2014-2020 Local Food Systems stresses their significance and need for further development.

\section{RESEARCH RESULTS}

\section{Consumer attitude}

Research carried out by the Eurobarometer (2011) revealed that there is a high interest in local products. Over half of the respondents (55\%) totally agreed and $37 \%$ tend to agree, that the EU should encourage local markets and short distribution channels to make them more available.

Moreover, as Figure 1 shows, $89 \%$ of respondents totally agreed and tend to agree, that buying local products bring benefits both to producers and to consumers. Only $5 \%$ tend to disagree about beneficial role of Local Food Systems, 2\% disagree while 4\% do not have opinion in this filed. Consumers asked about designation of Local Food Systems in 54\% claimed that implementation of labels identifying local products is needed (Eurobarometer, 2011). Consumer attitude to local product confirmed that Local Food Systems are gaining on popularity and can become an alternative for industrialized food system.

Important elements of Local Food Systems are direct sales processes and farmers markets. In the capital of Poland - Warsaw there are over 442 places with direct sale possibilities offering various goods, but in majority fresh agriculture products. Shopping at farmers markets has become an everyday habit of the inhabitants. Almost
$75 \%$ of respondents mentioned open-air markets as the best possibility for small shopping. What is more, agriculture products such as fruits and vegetables by $84 \%$ of respondents are the most desirable products (Research retrieved by Warszawske targowiska, 2009). Despite the popularity of Local Food Systems, the significance of Local Food Systems is worth to analyse.

Figure 1 Respondents` opinion about benefits connected with buying on local farms.

\section{There are benefits in buying products from a local farm}

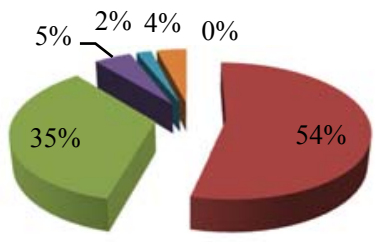

$$
\begin{aligned}
& \square \text { Totally agree } \quad \square \text { Tend to agree } \quad \square \text { Tend to disagree } \\
& \square \text { Totally disagree } \quad \text { No opinion }
\end{aligned}
$$

Source: own analysis based on "The Common Agricultural Policy", (Eurobarometer, 2011)

\section{Impact of Local Food Systems}

Increasing interests in local food occurred together with the decreasing quality of mass produced food products and increase in applying food preservatives, genetically modified crops or ingredients improving taste, colour or expanding shelf life. Thus, Local Food Systems can be perceived as "resistance and counter-pressure to conventional globalizing food systems" (Feagan, 2007).

Local Food Systems play crucial role in social, cultural, economic and environmental sustainability (Arfini et al., 2013). As it is written by Hinrichs (2000) Local Food Systems has been the "stepchild" of sustainable agriculture markets and organic low-input farmers. To prove this opinion, the arguments are presented below.

Hinrichs (2000) stated that "the impetus and nature of sustainable agriculture have generally been framed emphasizing either technological change and production practices (Bird et al., 1995; Buttel and Shulman, 1997) or social movements (Barham, 1997; Hassanein and Kloppenburg, 1995; Meares, 1997). Local Food Systems can be regarded as a social movement against destructive conventional, large-scale agricultural paradigm.

Social significance of LFS lays in direct contact between consumer and producer and their relationship. Social connections and trust are often seen as the main features that differ local from global food systems (Hinrichs, 2000). Sociologists estimate that people in farmers markets have 10 times more conversation than in supermarkets (Halweil, 2003). Direct relation creates social connection what can improve life in rural community. What is more, conscious consumers that value food quality take food origin and specification of 
production processes into consideration. Proximity of LFS guarantees perfect information about products. Information on the packaging or communicated personally at the point of retail enables consumers to make connections and associations with the place of production (Marsden et al., 2000) and process of production. Moreover, consumers have a sense of belonging to the community which produce those goods. Local foods systems claims to create community identity and can help overcome rural isolation (Local government, 2011). Social connections influence also the need to support what is local and what is produced in the neighbourhood. Appropriate information creates the added value to the product and allows to be outstanding from more anonymous commodities what is reflected on farmer's financial outcome (Marsden et al., 2000). Nevertheless, technical revolution and implementation of mass production succeed in global lowering of food prices simultaneously limiting farmers' profits. What is more, also increase of intermediaries in food supply chains caused limitation of profit for producers resulting in deterioration of living standards in rural areas. The proportion to the food value returning to the farmers has drastically shrunk (Pretty, 2001).

Data presented in Table 1. collected by the Central Statistical Office of Poland (2011) presents disproportion between prices available at open-air market and prices achieved at procurement, where food is bought up for further resale. The prices vary depending on the products; however prices at open-air markets are higher. Presence of many intermediaries in industrialized supply chains demands from farmers, which are the first unit in supply chain, minimum sale prices, so that all the supply chain participants could further achieve some profit.

Table 1 Prices of some agriculture products offered at farmers market and procurement

\begin{tabular}{|c|c|c|c|}
\hline & $\begin{array}{r}\text { Average } \\
\text { marketplace } \\
\text { prices of Major } \\
\text { agricultural } \\
\text { products } \\
\text { received by } \\
\text { Farmers (in } \\
\text { PLN, 2012) }\end{array}$ & $\begin{array}{r}\text { Average } \\
\text { procurement } \\
\text { prices of major } \\
\text { agricultural } \\
\text { products (in } \\
\text { PLN, 2012) }\end{array}$ & $\begin{array}{r}\% \\
\text { difference }\end{array}$ \\
\hline Cereals grain of wheat & 94.65 & 89.34 & 5.6 \\
\hline Cereals grain of rye & 80.85 & 74.23 & 8.2 \\
\hline Cereals grain of barley & 88.18 & 81.91 & 7.1 \\
\hline Edible potatoes per $\mathrm{dt}$ & 60.59 & 44.97 & 25.8 \\
\hline
\end{tabular}

Local Food Systems change proportion of profits divided within supply chain. Another economic advantage of Local Food Systems is the fact that money spent in short food supply, spent locally, remains in the region. This money generates multiplier effect, factor close to three, at regional income communities (Committee of Regions, 2011). Simultaneously, there is a greater chance for development, trade or employment (Dower, 2011). When income is spent locally, for local or regional products, it supports local and regional economy. What is more, investments in LFS triggered either economy recovery, increase in entrepreneurship or change of rural area image. Going step ahead, increase in farmer's profits gives them chances for ecological and environmental friendly production growth. If farmers are receiving small proportion of food value they do not have income to produce without causing damage to environment and without application of e.g. productivity fertilizers.

Local Food Systems environmental advantage is obtained mainly by its ecological and sustainable production processes as well as by short distribution channels. Food produced locally is sold in short supply chains limiting food miles, meaning the distance which food has to cover from producer to final consumer. Transportation relies on burning fossil fuels, which releases gases, including carbon dioxide. As a result of short transportation distance, decrease of carbon emission to the environment and usage of energy resources is observed. As a result of short transportation distance, decrease of carbon emission to the environment and usage of energy resources is observed. The carbon footprint of products from LFS is much lower than commodities distributed in complex supply chains (Local government, 2011). What is more, due to the short or zero transportation distance there is no need to use preservatives expanding shelf life, affecting nutritional value of products. Long transportation distance imposes necessity of using chemical improvers which affect either food or environment. Local commodities usually reach consumers more quickly and more often at the peak of freshness. It is also likely that locally produced fruits and vegetables often have higher nutritional value (Irshad, 2010). Furthermore, agriculture and food systems are significant contributors to the greenhouse gas emissions, which is the main cause of climate change. Local Food Systems gives great contribution to limit those changes (Irshad, 2010) and support sustainable growth.

Mass production and specialisation in agriculture influence agriculture unification. Large scale production is often limited to a single species per field or very little genetic diversity within the species (Irshad, 2010). Lack of diversity often results in soil erosion and increase of non-productive ecosystems. In contrary, LFS are a great support for sustaining biodiversity by development of rare spices or diverse production. Taking into account environmental effects it is also worth mentioning that products sold via short supply chains do not need complex packaging which production also affects environment and the use of natural resources. Thanks to that, a reduction of waste disposal is obtained (Irshad, 2010).

\section{CONCLUSIONS}

Local Food Systems are undoubtedly gaining on popularity either among consumers from big cites aware of nutritional diet or people living in rural areas with access to local markets. Choosing "local" is not only the 
expression of healthcare, but also consciousness about quality and sustainability. Local Food Systems favour positive externalities through sustainable production, indeed playing crucial role for economy, environment and society. Conscious consumers are seeking for precise features that food products must cover, i.e. freshness, taste, nutritional value, safe and known origin. All these features are the basic components characterising Local Food Systems products. Thus, consumers seeking for quality should choose products available on local markets. Nevertheless, local systems do not have possibilities to replace intensive, global systems; however can become great alternative beneficial for consumers as well as for environment.

\section{REFERENCES}

ARFINI, F. - BELLETTI G. - MARESCOTTI, A. VANDECANDELAERE, E. 2009. Linking people, places and products. FAO. p. 3-30

BARHAM, M.E. 1997. Social movements for sustainable agriculture in France: a Polanyian perspective. Society and Natural Resources, vol. 10. Issue 3. 239-249.

http://dx.doi.org/10.1080/08941929709381023

BIRD, E.A.R. - BULTENA, G.L. - GARDNER, J. C. eds. 1995. Planning the Future. Iowa State University Press, Ames.

BUTTEL, F.H. - SHULMAN, S.W. 1997. Introduction to the special issue on the politics and policies of sustainable agriculture. Society and Natural Resources $\begin{array}{llll}\text { vol } 10, & \text { Issue } & 3 . & 235-237\end{array}$ http://dx.doi.org/10.1080/08941929709381022

DOWER, M. 2011. Local and short food supply chains. Report on the outcome of workshop A. towards an appropriate policy framework $\mathrm{p}$ 1-5. http://ec.europa.eu/agriculture/events/2012/smallfarmers-conference/conclusions-workshop-a en.pdf EUROBAROMETER, 2011. The Common Agricultural Policy. European Commission. 65 pp. Retrieved: $\underline{\mathrm{http} / / \text { ec.europa.eu/public_opinion/archives/ebs/ebs_368 }}$ en.pdf

FEAGAN, R. 2001. The Place of Food: Mapping out The 'Local' in Local Food Systems. Progress in Human Geography, 31(1), 23-42 doi: $\underline{10.1177 / 0309132507073527}$

GLOWNY URZAD STATYSTYCZNY (CSO CENTRAL STATISTIC OFFICE). 2012. Rynek wewnetrzny w 2012r. Warszawa.

HALWEIL, B. 2003. The Argument for Local Food. World Watch. May/June, Vol. 16, Issue 3.pg.20.

HASSANEIN, N. - KLOPPENBURG, J.R. 1995. Where the Grass Grows Again: Knowledge Exchange in the Sustainable Agriculture Movement. Rural Sociology, Vol. 60, Issue 4., 721-740 http://dx.doi.org/10.1111/j.1549-0831.1995.tb00603.x HINRICHS, C. 2000. Embeddedness and local food systems: notes on two types of direct agriculture market. Journal of Rural Studies 16(3), 295-303. http://dx.doi.org/10.1016/S0743-0167(99)00063-7
ILBERY, B. - MAYE, D. 2006. Retailing Local Food in the Scottish-English Borders: a Supply Chain Perspective. Geoforum, Volume 37, Issue 3. p. 352-367 IRSHAD, H., 2010. Local Food - A Rural Opportunity. Rural Development Division in Alberta. p. 1-30

EUROPEAN COMMISSION. 2013. European Parliament and the Council Report on the labeling system for a local agriculture and direct sales, $\operatorname{COM}(2013) \quad 866, \quad$ p. $1-12$, http://ec.europa.eu/agriculture/quality/local-farmingdirect-sales/pdf/com-report-12-2013 pl.pdf COMMITTEE OF THE REGIONS. 2011. Draft outlook opinion Committee of the Regions . Local food systems. 2011/C 104/01

http://lokalnazywnosc.pl/sites/default/files/zalaczniki/lok alne systemy zywnosciowe - korzysci 0.pdf LOCAL GOVERNMENT REGULATION, A LOCAL AUTHORITY SURVEY. 2011. Buying food with geographical descriptions, How "local" is "local"? p.121, Devon County Council, http://www.devon.gov.uk/es/print/lgr -

how local is local report - february 2011.pdf

MARSDEN, T. - BANKS, J. - BRISTOW, 2000. Food Supply Chain Approaches: Exploring Their Role in Rural Development. Sociologia Ruralis, vol 40, no 4. P. 425 436

MEARES, A.C. 1997. Making the transition from conventional to sustainable agriculture: gender, social movement participation and quality of life on the family farm. Rural Sociology 62 (1). p. 21-47 http://dx.doi.org/10.1111/j.1549-0831.1997.tb00643.x

PRETTY, J. 2001. Some Benefits and Drawbacks of Local Food Systems, Briefing Note for TVU/Sustain AgriFood Network. November 2nd 2001 p. 1-11 http://www.sustainweb.org/pdf/afn_m1_p2.pdf

PRZEGLAD OBSZAROW WIEJSKICH UE. 2012. Lokalna Zywnose i krotkie lancuchy dostaw. Magazyn Europejskiej Sieci na rzecz Rozwoju Obszarow Wiejskich, (Local Food and short supply chains. Magazine from the European Network for Rural Development) Volume 12. p. 2-62 http://enrd.ec.europa.eu/enrd-static/fms/pdf/3E98A87AD891-43FB-E462-70E329C064EC.pdf

RENTING, H. - MARSDEN, T. - BANKS, J. 2003. Understanding alternative food networks: exploring the role of short supply chains in rural development, Environment and Planning A, volume 35 (3), pages 391411. http://dx.doi.org/10.1068/a3510

ZEGAR, J.S. 2012. Współczesne wyzwania rolnictwa, (Contemporary challenges of agriculture )Warszawa, PWN, p. 15-35

WARSZAWSKE TARGOWISKA, 2009, Report about open-air markets In Warsaw, retrieved by http://www.targowiska.um.warszawa.pl/TargowiskaArtic le.aspx? article=opiniaWarszawiakow 